\title{
Sociobiology
}

RESEARCH ARTICLE - WASPS

\section{Diversity and Structure of Social Wasps Community (Hymenoptera: Vespidae, Polistinae) in Neotropical Dry Forest}

\author{
T Elisel', E Valadares ${ }^{1}$, Fa Albuquerque ${ }^{2}$, CF Martins ${ }^{1}$ \\ 1 - Universidade Federal da Paraíba, Programa de Pós-Graduação em Ciências Biológicas (Zoologia)/CCEN, João Pessoa-PB, Brazil \\ 2 - Empresa Brasileira de Pesquisa Agropecuária (EMBRAPA), Campina Grande-PB, Brazil
}

\section{Article History}

\section{Edited by}

Gilberto M. M. Santos, UEFS, Brazil

Received 28 November 2016

Initial acceptance 12 December 2016

Final acceptance 13 February 2017

\section{Keywords}

Biodiversity, Survey, Caatinga, Semi-arid, Intercropping.

\section{Corresponding author \\ Thiago Elisei \\ Universidade Federal da Paraíba \\ Programa de Pós-Graduação em Ciências \\ Biológicas (Zoologia)/CCEN \\ João Pessoa-PB, Brasil \\ E-Mail: thiagoelisei@gmail.com}

Publication date 29 May 2017

\begin{abstract}
Social wasps are potential predators of agricultural pest species. The objective of this study was to conduct a survey of the community of social wasps (Polistinae species) that inhabit the neotropical dry forest named Caatinga of Paraiba, Northeast of South America (Brazil), and to compare the richness and abundance of wasps located in areas of Caatinga with those inhabiting areas of organic intercropping farming. The present study sampled 10 Polistinae species distributed in six genera. Two new species were registered for the state. The comparison between the community of social wasps of the Caatinga showed that there was not statistical difference in the richness and abundance between the natural vegetation and organic intercropping. This means that agroecosystem attracted community of Polistinae, promoting the maintenance of social wasps in anthropic environment and possibly favoring biological control.
\end{abstract}

\section{Introduction}

The several Brazilian ecosystems have different characteristics resulting in specificity in certain animal groups, including wasps. In this context, stands out the tropical dry forests of Northeastern Brazilian semi-arid region, which is characterized by technical criteria as a region with the average annual rainfall of less than $800 \mathrm{~mm}$, irregularly distributed in space and time, and the risk of increased drought in $60 \%$ (Brazil, 2007). Northeastern Brazil is composed by $90 \%$ of semi-arid climate, where Neotropical dry forests are found in areas with very specific characteristics called Caatinga (Brazil, 2007). This biome is characterized by tropical dry forest with an increase on resource supply in the rainy periods (Pereira Filho et al., 2013).

The Caatinga biodiversity is considered to be the lowest when compared to other areas of Brazil (see Ducke, 1907). Lewinsohn (2000) emphasized the importance of surveys on the biodiversity for this biome. Brandão et al. (2000) revealed the lack of studies on invertebrates for the Northeast region. Recent studies in the Caatinga have showed that the fauna and flora were underrated and also revealed important adaptations of its organisms to the irregular rainfall (Leal et al., 2005). In addition, the knowledge of its diversity is very important to understanding the environmental changes caused by human activities or by natural factors, including climate changes (Lawton et al., 1998). The Caatinga is considered a very important biome in the discovery of new species and new records, once it is understudied and has a long history of deforestation and fragmentation, mainly by human activities (Guérnard, 2014).

Social wasps surveys in Brazilian tropical dry forests were made mainly in the Bahia state, which is responsible for the majority of Polistinae diversity found in the semi-arid region (Aguiar \& Santos, 2007; Santos et al., 2007; Santos et al., 2009; Andena \& Carpenter, 2014). In Paraiba state no surveys of social wasps were carried out. The diversity of this group is known only by studies of associated entomofauna 
and floral visitors. Only nine species of Polistinae were recorded for Paraiba (Andena \& Carpenter, 2014). The aim of this study was to accomplish a survey of the Polistinae species in the Paraiba dry forest, and compare the richness, abundance and composition between the natural vegetation and intercropping on organic farms.

\section{Material and Methods}

\section{Study area}

This study was carried out from 2013 to 2015 , in the cities of Sumé ( $7^{\circ} 40^{\prime} 18^{\prime}$ ' $\mathrm{S}, 36^{\circ} 52^{\prime} 54^{\prime}$ 'W) and Prata (7 ${ }^{\circ} 41^{\prime} 27^{\prime \prime S}, 37^{\circ} 4^{\prime} 48^{\prime \prime} \mathrm{W}$ ), both located in the Western Cariri of Paraiba, one of driest regions of the Brazil, in the northeast of South America. At these areas low mechanization and intercropping on organic farms are stablished. The region is predominantly agricultural and goat breeding with patches of tropical dry forest, characterizing the Caatinga biome. The rainy season occurs mainly between January to July (rainfall season), representing $78 \%$ of total annual precipitation (Sena et al., 2012).

\section{Methodology of survey}

The sample and transportation of specimens were authorized and certified by the Brazilian Institute of Environment and Renewable Natural Resources (IBAMA). Social wasps were sampled through attractive pet bottle trap and active search, guided by three transects of 100 meters length, 20 meters away one of the other. These transects were repeated in the farm areas as well as in the Caatinga area.

The wasps were captured through 60 traps (30 in each area), containing passion fruit juice concentrate and neutral detergent, distributed 10 per transect, distant from each other by 10 meters. These traps were exposed in the environment for five days per sample.

The active search was performed with hand net, in fixed periods of 20 minutes, walking close to the transects with attractive traps. The perpendicular distance of search on the track was limited to two meters on each side of the transects.

Social wasps specimens captured were placed in plastic pots containing $70 \%$ alcohol. In addition to the field survey, it was analyzed a material captured by EMBRAPA COTTON in Caatinga vegetation and intercrops areas, at Sumé city. EMBRAPA data were sampled in 2011 using Malaise traps.

\section{Data analyses}

The Relative Frequency and Constancy values were calculated from the data obtained for wasps species and abundance. The frequencies were determined by the proportion of individuals of a species on total of individuals of the sample, showed as a percentage. Constancy was calculated from the percentage of samples in which one particular species was present. The species were classified by their constancy, being CONSTANT (C) as present in over $50 \%$ of the samples; ACCESSORY (AA) as present in 25$50 \%$ of the samples; accidental (AL) as present at less than $25 \%$ of the samples. Analyses were performed in the EXCEL program.

The data was submitted to normality Shapiro-Wilk test (R-program). Analysis of the communities of wasps was performed in EstimateS (Version 9.1.0), in which the Shannon Wiener indices and Richness Estimators (Chao 1) were obtained. The Rarefaction Curve was built in EXCEL. The data of abundance and richness were used to check whether the Caatinga and Intercrop areas differ statistically. For this, the Wilcoxon test and Levene (R-program) were used.

\section{Species identification}

The sampled material was identified with the support of taxonomic keys, comparison with material deposited in the Entomological Collection of the State University of Feira de Santana, and by the specialist Dr. Sergio Andena, from this institution. The specimens were deposited in the Entomological collection of Department of Systematics and Ecology/UFPB.

\section{Results and Discussion}

\section{Social Wasps from Cariri, Paraiba, Brazil}

The survey resulted in 341 specimens of social wasps, from ten species in six genera (Table 1). The richness found was similar to that shown in the study of Santos et al., (2006) and Aguiar and Santos (2007) in the Caatinga of Bahia state. These authors reported, respectively, 12 and 13 species of social wasps as flower visitors. Nevertheless, Santos et al., (2009) registered a richness of 17 species in a survey of nests in Caatinga and Agricultural systems. However, the highest number of species was recorded in the rainy season, while in the dry season only 13 species were found.

The study recorded two new species of social wasps to Paraiba state: Polistes simillimus and Mischocyttarus cearensis, being also the first record of Mischocytarini tribe (Elisei et al., 2015). These two species had been reported to Caatinga, and found in other studies realized on Northeastern Brazil states (Santos et al., 2007; Melo et al., 2015). Andena and Carpenter (2014) registered only nine species of social wasps in Paraiba state, being the addition of those two new species a significant increase on the diversity of Polistinae.

The present study was carried out in a historic drought period (Table 2). Thus, richness may have been affected by this weather phenomenon, reducing diversity of social wasps, once they are influenced by environmental variations (Richter, 2000). This is so because with the decrease of nutrients, associated with reduced rainfall, also occurs a decline in search activity for resources (Jeanne, 1991; Resende et al., 2001; Lima \& Prezoto 2003; Elisei et al., 2005; Ribeiro Jr et 
Table 1. Abundance (N), Relative Frequency (F), Constancy value (C) and Constancy Category ( $\mathrm{C}=$ Constant; AA = Accessory; $\mathrm{AL}$ $=$ Accidental) Richness (S) and Shannon Diversity Index (H '), for social wasps collected in the cities of Sumé and Prata, Paraiba state.

\begin{tabular}{ccccc}
\hline Species & N & F (\%) & C\% & CONST \\
\hline Brachygastra lecheguana & 35 & 10.26 & 21.88 & $\mathrm{AL}$ \\
\hline Polybia ignobilis & 69 & 20.23 & 68.75 & $\mathrm{C}$ \\
\hline Polybia sericea & 43 & 12.61 & 12.50 & $\mathrm{AL}$ \\
\hline Polybia occidentalis & 112 & 32.84 & 75.00 & $\mathrm{C}$ \\
\hline $\begin{array}{c}\text { Polybia sp. grupo } \\
\text { occidentalis }\end{array}$ & 20 & 5.87 & 25.00 & $\mathrm{AA}$ \\
Protopolybia exigua & 21 & 6.16 & 28.13 & $\mathrm{AA}$ \\
\hline Polistes canadensis & 34 & 9.97 & 34.38 & $\mathrm{AA}$ \\
\hline Polistes simillimus & 1 & 0.29 & 3.13 & $\mathrm{AL}$ \\
Mischocyttarus cearensis & 3 & 0.88 & 9.38 & $\mathrm{AL}$ \\
\hline Protonectarina sylveirea & 3 & 0.88 & 9.38 & $\mathrm{AL}$ \\
\hline Total (N) & & & 341 & \\
\hline Richness (S) & & & 10 & \\
\hline Diversity (H') & & & 1.85 & \\
\hline
\end{tabular}

al., 2006; Elisei et al., 2013). Santos et al., (2009) and Souza et al., (2012) verified that the number of nests diminished with decreasing rainfall during the two seasons (dry and wet). On this way, rainfall is a very important factor on the Polistinae community dynamic.

Data analysis revealed that the sample effort recorded most of the species present in the areas $(\mathrm{S}=10$; Chao $1=$ 10). The rarefaction curve almost reached the assintote, fact that can explained by needed more intensive surveys in region and by rare species captured (Figure 1). When compared with other biomes, the Caatinga has a reduced diversity of social wasps. Diniz and Kitayama (1994) identified 30 species in Chapada dos Guimarães (savannah), Mato Grosso state. Silva et al. (2011) reported 31 species of social wasps in savannah, Maranhão state. Rodrigues and Machado (1982)

Table 2. Average annual Pluviosity for Sumé and Prata. Average observed and expected precipitation measured in millimeters* (mm). *Data: Executive Agency for Water Management in the State of Paraiba.

\begin{tabular}{ccccc}
\hline \multicolumn{5}{c}{ Sumé } \\
\hline & $\begin{array}{c}\text { Observed } \\
(\mathrm{mm})\end{array}$ & $\begin{array}{c}\text { Expected } \\
(\mathrm{mm})\end{array}$ & $\begin{array}{c}\text { Deficit } \\
(\mathrm{mm})\end{array}$ & Deficit (\%) \\
2012 & 27 & 559.3 & -532.3 & -95.2 \\
2013 & 254.4 & 559.3 & -304.9 & -54.5 \\
2014 & 726,1 & 559,3 & 166,8 & 29,8 \\
2015 & 220.4 & 559.3 & -338.9 & -60.6 \\
& & & Prata & \\
2012 & 152.8 & 745.6 & -592.8 & -79.5 \\
2013 & 445.7 & 745.6 & -299.9 & -40.2 \\
2014 & 603.9 & 745.6 & -141.7 & -19 \\
2015 & 317.6 & 745.6 & -428 & -57.4 \\
\hline
\end{tabular}

found 33 species in the São Paulo state, in areas of savannah, eucalyptus and secondary forest. Tanaka Junior and Noll (2011) collected 29 species in semideciduous seasonal forest fragments in São Paulo state. Marques et al., (1993) recorded 20 species for Atlantic Forest. In the Pará state, Silva and Silveira (2009) found 65 species and in other areas of the Amazon forests, as in Roraima (Raw, 1992; 46 species) and Rondônia (Raw, 1998; 36 species), the number of species was much higher than recorded in this present study and other Brazilian ecosystems.

The species with the highest abundance was Polybia occidentalis $(\mathrm{n}=112, \mathrm{~F}=32.84 \%)$, followed by Polybia ignobilis $(\mathrm{n}=69, \mathrm{~F}=20.23 \%$ ) (Table 1). Melo et al., (2015) reported these species also had the major abundance and constancy in the Caatinga, Bahia state. Other similar studies showed $P$. occidetalis and $P$. ignobilis as abundant and constant in tropical dry forests of Brazil (Aguiar \& Santos

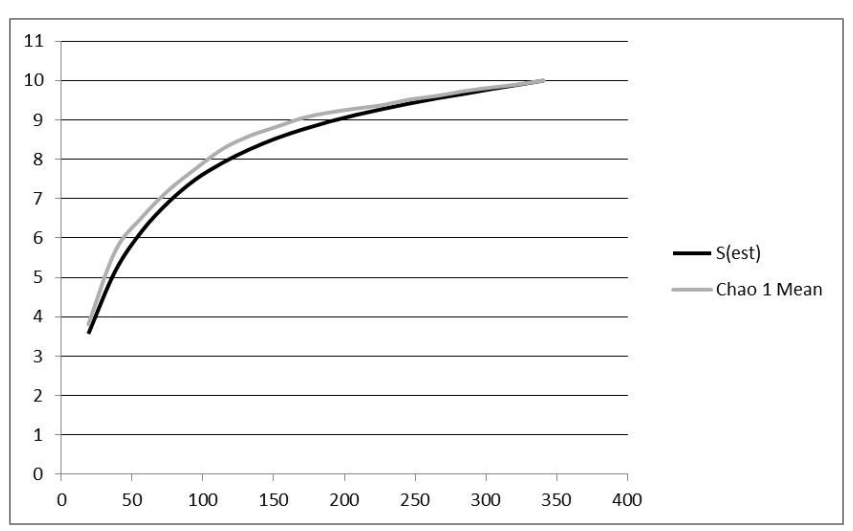

Fig 1. Rarefaction curve of social wasp species collected in the Caatinga, Paraiba state, Brazil $(\mathrm{S}=$ observed diversity, Chao $1=$ estimated diversity).

\section{7; Santos et al., 2006; Santos et al., 2007).}

Polybia genus comprised $72 \%$ of the trapped samples (Figure 2). This value may be related with the swarm founding behavior of this genus, which guaranteed the more success in foundation (Jeanne, 1991). Another characteristic is that the nests of Polybia have a protective envelope, creating a better micro climate for the colony members inside (Richard \& Richard, 1951). In addition, this genus has been reported as having a high storage capacity of protein resources and carbohydrates (Ihering, 1896; Machado, 1984), which confers resistance to periods of environmental stress, such as the long drought period in the semi-arid (Jeanne, 1991).

Polistes canadensis was considered accessory, and was found in $38 \%$ of the samples. The studies conducted in Caatinga by Santos (2006), Silva-Pereira and Santos (2007), Santos et al. (2007) and Santos et al. (2009) showed the same species with high abundance and significant constancy. The Polistes genus is characterized by building nests without protective envelope. This absence may result in lower internal control of the nests in relation to the environmental variables (Jeanne, 1991). In the period of the present study occurred a 
deficit in rainfall of $50 \%$ below historical averages (AESA, 2016). The decrease in water supply and, as a result, the fall in the supply of nutrients, may have resulted in the decline of this group in the study area. This means that, because of sensitivity to environmental variations, social wasps can be used as bioindicators of environment quality. Souza et al. (2010) verified preference by some species to different environmental and appoint someone's as bioindicators.

Polistes simillimus had the lowest constancy in samples, because just one specimen was captured. Mischocyttarus cearensis, Polybia sericea, Protonectarina sylveirea and Brachygastra lecheguana were considered accidental species (Table 1). However, in other research also conducted in areas of Caatinga, some of these wasps were classified as accessory or constant, as B. lecheguana, $P$. sericea and $P$. sylveirea by Santos et al. (2006); M. cearensis and P. simillimus by Melo et al. (2015). The lack of previous surveys in the region affects discussions, for example a possible reduction on the wasps populations.

Santos et al. (2009) reported a higher number of active colonies of social wasps in the wet period of the year in the Caatinga. Polistinae populations are strongly influenced by environment, and those euriecias are most resistant to unfavorable changes than estenoecias (Souza, 2010). The present research can strengthen the influence of drought on the dynamics of the captured Polistinae community in Caatinga, resulting in a reduced abundance of certain populations. The predictions indicate that global warming will result in an intensification of drought extremes in the Brazilian Northeast (Marengo, 2006). Thus, surveys of different groups in the region are very important to determine the loss of biodiversity

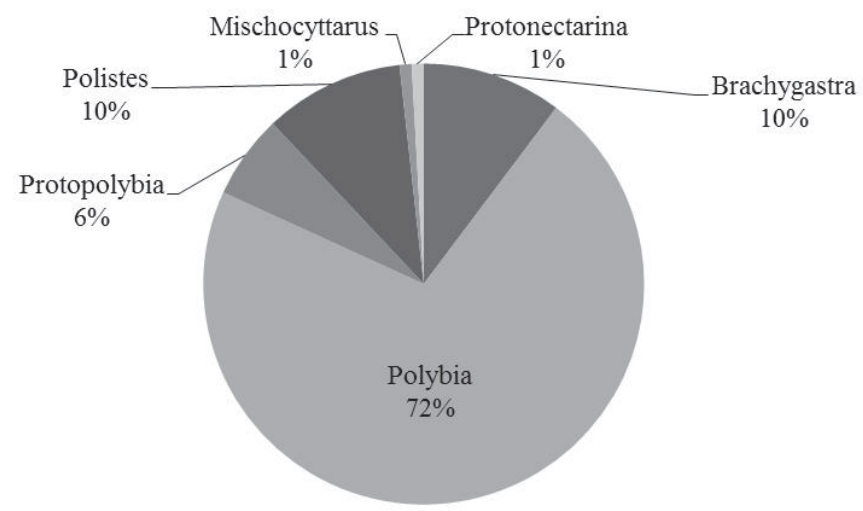

Fig 2. Abundance of social wasps genera captured in semi-arid, municipalities of Sumé and Prata, Paraiba state, Brazil.

due this phenomenon (Lawton et al., 1998).

Comparative analysis of social wasps communities in Caatinga and organic intercropping

There was no statistical difference of richness between the Caatinga vegetations and intercropping areas (Wp-value $=0.2994)$ (Figure 3 , Table 3 ). Intercropping areas showed a higher number of individuals although there was no significant difference between the abundances in the analyzed areas $(\mathrm{Wp}$-value $=0.4663)($ Figure 3 , Table 3$)$. In addition, the Levene Homogeneity Test revealed that Caatinga and intercrop showed homocedasticity (Lp-value $=0.6562)$, confirming the similarity between abundances.

The results of this study were similar to those registered in Santos et al. (2009). These authors verified no significant differences among richness of Polistinae in Caatinga and crop areas (cowpea, corn and beans). However, they found a greater number of social wasp nests founded in crop area, which can explain the high abundance in the cultivated area reported in the present study.

It is known that heterogeneous environments, with higher diversity of plants, tend to have an elevate number of niches and, thus, to promote the highest number of coexisting species (Latham \& Ricklefs, 1993; Bragança et al., 1998). The Caatinga is an environment more heterogeneous than monoculture crops. However, the plantation in the study areas is done with consortia of different types of vegetables (mainly: beans, corn, cotton, peanuts and sesame). Thus, the intercropping may exercise more attraction to individuals than the natural environment area. Altieri et al. (2003) highlighted the importance of biodiversity in plantations, especially in areas where it applies the Integrated Pest Management, once biodiversity favors the maintenance of
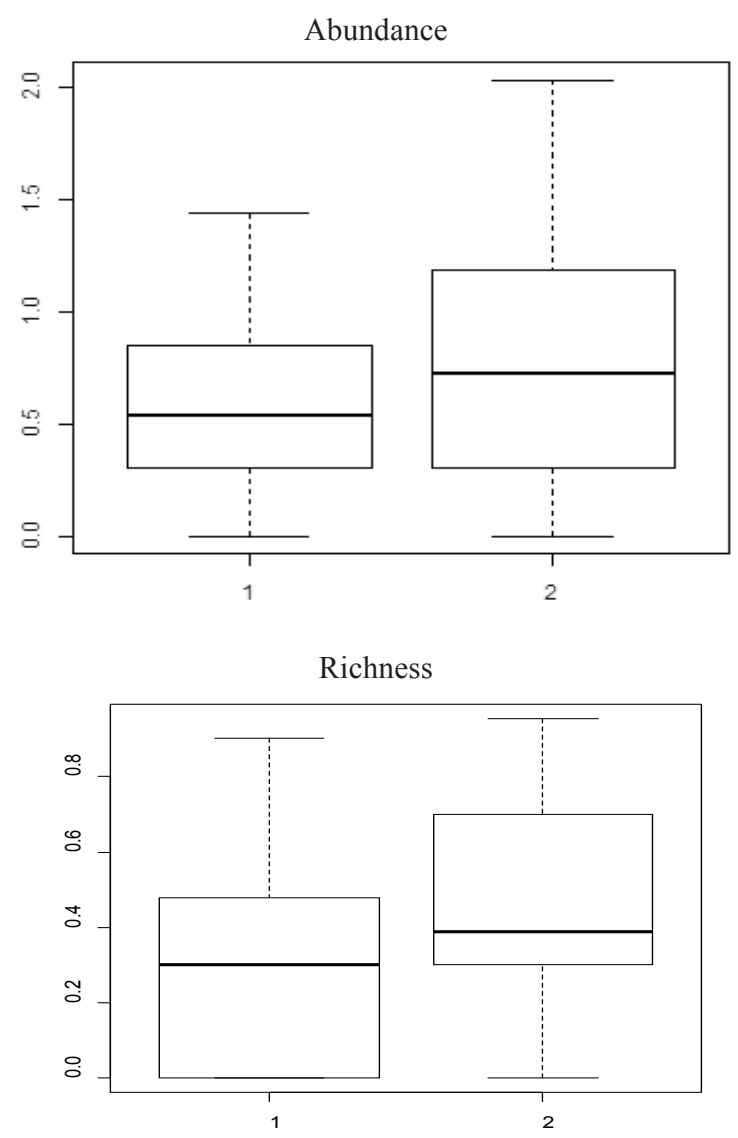

Fig 3. Abundance and Richness of social wasps captured in Caatinga (1) and Intercropping (2), in the cities of Sumé and Prata, Paraiba state, Brazil. 
natural enemy species of pests.

The most abundant species was $P$. occidentalis, both in intercropping and in the Caatinga, and was classified as constant in the two study areas (Table 3). This species has been reported as floral visitor and predator of caterpillar, exerting an important role in crop production (Gravena, 1983; Gobbi et al., 1984; Resende et al., 2001; Santos et al.,
2006; Nadia et al., 2007).

Surveys registered lower diversity of social wasps in monocultures when compared to natural vegetation (Santos, 1996; Souza et al., 2011; Silva et al., 2013.). Hence, our results suggest that intercropping may have an important role in the maintaining of community Polistinae in Paraiba Caatinga. Social wasps are natural enemies of pest species, thus it is important to favor their populations in environments with

Table 3. Abundance (N), Relative Frequency (F), Constance (C) and Category of Constancy (CONST; C $=>50 \%$; AA = 25\% $50 \%$; $\mathrm{AL}=<25 \%$ ), Richness (S) and Shannon diversity index ( $\mathrm{H}$ ') of social wasps collected in the Caatinga and Intercropping, Sumé and Prata cities, Paraiba state, Brazil.

\begin{tabular}{|c|c|c|c|c|c|c|c|c|}
\hline \multirow{2}{*}{ Species } & \multicolumn{4}{|c|}{ Caatinga } & \multicolumn{4}{|c|}{ Intercropping } \\
\hline & $\mathrm{N}$ & $\mathrm{F}(\%)$ & $\mathrm{C} \%$ & CONST & $\mathrm{N}$ & $\mathrm{F}(\%)$ & $\mathrm{C} \%$ & CONST \\
\hline Brachygastra lecheguana & 6 & 5.41 & 11.11 & $\mathrm{AL}$ & 29 & 12.61 & 35.7 & $\mathrm{AA}$ \\
\hline Polybia ignobilis & 24 & 21.62 & 55.56 & $\mathrm{C}$ & 45 & 19.57 & 85.7 & $\mathrm{C}$ \\
\hline Polybia sericea & 8 & 7.21 & 11.11 & $\mathrm{AL}$ & 35 & 15.22 & 14.3 & $\mathrm{AL}$ \\
\hline Polybia occidentalis & 39 & 35.14 & 77.78 & $\mathrm{C}$ & 73 & 31.74 & 71.4 & $\mathrm{C}$ \\
\hline Polybia sp. grupo occidentalis & 8 & 7.21 & 16.67 & $\mathrm{AL}$ & 12 & 5.22 & 35.7 & AA \\
\hline Protopolybia exigua & 8 & 7.21 & 27.78 & AA & 13 & 5.65 & 28.6 & AA \\
\hline Polistes canadensis & 16 & 14.41 & 38.89 & AA & 18 & 7.83 & 28.6 & AA \\
\hline Polistes simillimus & 0 & 0.00 & 0.00 & - & 1 & 0.43 & 7.1 & $\mathrm{AL}$ \\
\hline Mischocyttarus cearensis & 1 & 0.90 & 5.56 & $\mathrm{AL}$ & 2 & 0.87 & 14.3 & $\mathrm{AL}$ \\
\hline Protonectarina sylveirea & 1 & 0.90 & 5.56 & $\mathrm{AL}$ & 2 & 0.87 & 14.3 & $\mathrm{AL}$ \\
\hline Total $(\mathrm{N})$ & \multicolumn{4}{|c|}{111} & \multicolumn{4}{|c|}{230} \\
\hline Richness (S) & \multicolumn{4}{|c|}{9} & \multicolumn{4}{|c|}{10} \\
\hline Diversity (H') & \multicolumn{4}{|c|}{1.76} & \multicolumn{4}{|c|}{1.85} \\
\hline
\end{tabular}

organic agriculture (Parra et al., 2002).

\section{Conclusion}

Caatinga has a neglected knowledge of its biodiversity, and requires more detailed studies about various groups, including social wasps. The data increased the number of Polistinae species registered for the Paraiba state. In addition, the comparison between the social wasps community of the natural environment (Caatinga) and intercropping, reinforced the importance of diversity in crops, favoring the maintenance of the natural enemy species.

\section{Acknowledgments}

We thank Prof. Dr. Ricardo Andena, from the State University of Feira de Santana for wasp identification, and the Brazilian National Council for Scientific and Technological Development (CNPq) for the financial support.

\section{References}

Agência Executiva de Gestão das Águas do Estado da Paraíba (AESA). Monitoramento de chuvas acumuladas. http://www. aesa.pb.gov.br/. (Acessed date: 18 September, 2016).

Aguiar, C. M.L. \& Santos, G. M. de M. (2007). Compartilhamento de recursos florais por vespas sociais (Hymenoptera: Vespidae) e abelhas (Hymenoptera: Apoidea) em uma área de Caatinga. Neotropical Entomology, 36: 836842. doi:10.1590/S1519-566X2007000600003

Altieri, A.M., Silva, E.N. \& Nicholls, C.I.(2003). O papel da biodiversidade no manejo de pragas. Holos Editora, 226 p.

Andena, S.R. \& Carpenter, J.M. (2014). Checklist das espécies de Polistinae (Hymenoptera, Vespidae) do semiárido brasileiro; pp 169-180, in: Bravo, F., Calor, A. (Eds). Printmídia. Artrópodes do Semiárido, Biodiversidade e Conservação. Feira de Santana.

Aragão, M \& Andena, S.R. (2016). The social wasps (Hymenoptera: Vespidae: Polistinae) of a fragment of Atlantic Forest in southern Bahia, Brazil. Journal of Natural History, 50: 1411-1426. doi: 10.1080/00222933.2015.1113317.

Bonfim, M.G.C.P \& Antonialli Junior, W.F. (2012). Community structure of social wasps (Hymenoptera: Vespidae) in Riparian Forest in Batayporã, Mato Grosso do Sul, Brazil. Sociobiology, 59: 755-765. 
Bragança, M.A.L., Zanuncio, J. C., Picanço, M. C. \& Laranjeiro, A.J.(1998). Effects of environmental heterogeneity on Lepidoptera and Hymenoptera populations in Eucalyptus plantations in Brazil. Forest Ecology and Management, 103: 287-292. doi:10.1016/S0378-1127(97)00226-0

Brandão, C.R.F., Cancello, E.M. \& Yamamoto, C.I. (2000). Avaliação do estado atual do conhecimento sobre a diversidade biológica de invertebrados terrestres no Brasil. Relatório final, p 141-147. In: Lewinsohn, T. (Ed.). Avaliação do estado do conhecimento da diversidade biológica do Brasil. MMAGTB/CNPq - NEPAM/UNICAMP.

Brasil. Ministério da Integração Nacional. Nova delimitação do semiárido brasileiro. Brasília, DF, 2007. http://www. integracao.gov.br. (Accessed date: 10 October, 2016).

Carpenter, J.M. \& Marques, O.M. (2001). Contribuição ao estudo dos vespídeos do Brasil (Insecta, Hymenoptera, Vespoidea, Vespidae). Publicações digitais, 2. Universidade Federal da Bahia.

Diniz, I.R. \& Kitayama, K. (1994). Colony densities and preferences for nest habitats of some social wasps in Mato Grosso State, Brasil (Hymenoptera: Vespidae). Journal of Hymenoptera Research, 3: 133-143.

Ducke, A. (1907). Connaissance de la faune Hyménoptérologique du nord-est du Brésil. Revue D'entomologique, 23: 73-96.

Elisei, T.; Guimarães, D.L.; Ribeiro Jr., C. \& Prezoto, F. (2005). Foraging activity and nesting of swarm-founding wasp Synoeca cyanea (Hymenoptera: Vespidae, Polistinae). Sociobiology, 46: 317-327.

Elisei T., Nunes J.V., Ribeiro Junior C., Fernandes Junior A.J. $\&$ Prezoto F. (2013). What is the ideal weather for social wasp Polistes versicolor (Olivier) go to forage? EntomoBrasilis, 6: 214-216. doi:10.12741/ebrasilis.v6i3.342

Elisei T., Albuquerque, F.A., Andena, S. R. \& Martins, C.F. (2015). New records of social wasps in the state of Paraíba, Brazil. Check List, 11: 1600. doi:10.15560/11.2.1600

Elpino-Campos, A., Del-Claro, K. \& Prezoto, F. (2007). Diversity of social wasps (Hymenoptera: Vespidae) in Cerrado fragments of Uberlândia, Minas Gerais State, Brazil. Neotropical Entomology, 36: 685-692. doi:10.1590/S1519566X2007000500008

Freitas, J. L., Pires, E.P., Oliveira, T.T.C., Santos, N.L. dos \& Souza, M. M. (2015). Vespas sociais (Hymenoptera: Vespidae) em lavouras de Coffea arabica L. (Rubiaceae) no Sul de Minas Gerais. Revista Agrogeoambiental, 7: 67-77. doi: 10.18406/2316-1817v7n32015684

Gobbi, N., Machado, V.L.L. \& Tavares-Filho, J.A. (1984). Sazonalidade das presas utilizadas na alimentação de Polybia occidentalis occidentalis (Olivier, 1791) (Hym., Vespidae).
Anais da Sociedade Entomológica do Brasil, 13: 63-69.

Gravena, S. (1983). Táticas de manejo integrado do bicho mineiro do cafeeiro Perileucoptera coffeella (GuérinMéneville, 1842): I Dinâmica populacional e inimigos naturais. Anais da Sociedade Entomológica do Brasil, 12: 61-71.

Grandinete, Y.C. \& Noll, F.B. (2013). Checklist of social (Polistinae) and solitary (Eumeninae) wasps from a fragment of Cerrado "Campo Sujo" in the State of Mato Grosso do Sul. Sociobiology, 60: 101-106.

Guénard, B., Weiser, D.M. \& Dunn, R.R. (2012). Global models of ant diversity suggest regions where new discoveries are most likely are under disproportionate deforestation threat. Proceedings of the National Academy of Sciences, USA, 19: 7368-7373. doi: 10.1073/pnas.1113867109

Ihering, H. von. (1896). E'état das guêpes sociales du Brésil. Bulletin de la Société Zoologique de France, 21: 159-162.

Jacques, G.C., Souza, M.M., Coelho, H.J., Vicente, L.O. \& Silveira, L.C.P. (2015). Diversity of social wasps (Hymenoptera: Vespidae: Polistinae) in an agricultural environment in Bambuí, Minas Gerais, Brazil. Sociobiology, 62: 439-445.

Jacques, G.C., Castro, A.A., Souza, G.K., Silva-Filho, R., Souza, M.M. \& Zanuncio, J.C. (2012). Diversity of social wasps in the Campus of the "Universidade Federal de Viçosa" in Viçosa, Minas Gerais State, Brazil. Sociobiology, 59: 1053-1062.

Jeanne, R.L. (1991). The swarm-founding Polistinae. In: Ross, K. G., Matthews, R. W. (eds.). The Social Biology of Wasps. Ithaca: Cornell University Press, p. 191-231.

Latham, R.E. \& Ricklefs, R.E. (1993). Global patterns of tree species richness in moist forests: energy-diversity theory does not account for variation in species richness. Oikos, 67: 325 333. doi: $10.2307 / 3545479$

Lawton, J. H., Bignell, D.E., Bolton, B., Bloemers, G.F., Eggleton, P., Hammond, P.M., \& Stork, N.E. (1998). Biodiversity inventories, indicator taxa and effects of habitat modification in tropical forest. Nature, 391(6662): 72-76. doi: $10.1038 / 34166$

Leal, I.R., Tabarelli, M. \& Silva, J.M.C. (2003). Ecologia e conservação da Caatinga. Editora Universitária, Universidade Federal de Pernambuco.

Lewinsohn, T. (2000). Avaliação do estado do conhecimento da diversidade biológica do Brasil. MMA- GTB/CNPq NEPAM/UNICAMP. 520p.

Lima, M.A.P. \& Prezoto, F. (2003). Foraging activity rhythm in the Neotropical swarm-founding wasp Polybia platycephala sylvestris Richards, 1978 (Hymenoptera: Vespidae) in different seasons of the year. Sociobiology, 42: $745-752$. 
Locher, G.A., Togni, O.C., Silveira, O.T. \& Giannotti, E. (2014). The social wasp fauna of a Riparian Forest in Southeastern Brazil (Hymenoptera, Vespidae). Sociobiology, 61: 225-233.

Machado, V.L.L. (1984). Análise populacional de colônias de Polybia (Myrapetra) paulista (Ihering 1896) (Hymenoptera, Vespidae). Revista Brasileira de Zoologia, 2: 187-201. doi: 10.1590/S0101-81751983000400001

Marengo, J.R. (2006). Mudanças Climáticas Globais e seus Efeitos sobre a Biodiversidade: Caracterização do Clima Atual e Definição das Alterações Climáticas para o Território Brasileiro ao Longo do Século XXI. Brasília: MMA, 212 p.

Marques, O.M., Carvalho, C.A.L. \& Costa, J.M.( 1993). Levantamento das espécies de vespas sociais (Hymenoptera, Vespidae) no Município de Cruz das Almas- Estado da Bahia. Insecta, 2: 1-9. doi:10.1590/S1519-566X2009000300003

Melo, A.M., Barbosa, B.C., Castro, M.M., Santos, G.M.M. \& Prezoto, F. (2015). The social wasp community (Hymenoptera, Vespidae) and new distribution record of Polybia ruficeps in an area of Caatinga Biome, northeastern Brazil. Check ListOnline, 11: 1530. doi:10.15560/11.1.1530

Mello, M.A.R., Santos, G.M.M., Mechi, M. R., Hermes, M. G. 2011. High generalization in flower-visiting networks of social wasps. Acta Oecologica, 37: 37-42.

Nadia, T.L., Machado, I.C. Lopes \& A.V. (2007). Polinização de Spondias tuberosa Arruda (Anacardiaceae) e análise da partilha de polinizadores com Ziziphus joazeiro Mart. (Rhamnaceae), espécies frutíferas e endêmicas da caatinga. Revista Brasileira de Botânica, 30: 89-100. doi: 10.1590/ S0100-84042007000100009

Parra, J.R.P., Botelho, P.S.M., Correa-Ferreira, B.S. \& Bento, J.M.S. (2002). Controle biológico no Brasil: parasitóides e predadores. Manole Press, São Paulo. 609p.

Pereira Filho, J.M., Silva, A.M. de A. \& Cézar, M.F. (2013). Manejo da Caatinga para produção de caprinos e ovinos. Revista Brasileira de Saúde e Produção Animal, 4: 77-90. doi: 10.1590/S1519-99402013000100010

Prezoto, F. \& Clemente, M.A. (2010). Vespas sociais do Parque Estadual do Ibitipoca, Minas Gerais, Brasil. MG Biota, 3: 22-32.

Prezoto, F., Santos-Prezoto, H. H., Machado,V. L.L. \& Zanuncio, J. C.(2006). Prey Captured and Used in Polistes versicolor (Olivier) (Hymenoptera: Vespidae) Nourishment. Neotropical Entomology, 35: 707-709. doi:10.1590/S1519566X2006000500021

Prezoto, F., Giannotti, E. \& Machado, V.L.L. (1994). Atividade forrageadora e material coletado pela vespa social Polistes simillimus Zikán, 1951 (Hymenoptera, Vespidae). Insecta, 3: 11-19.
Raw, A. (1992). The forest: savanna margin and habitat selection by Brazilian social wasps (Hymenoptera, Vespidae). In: Furley, P. A.; Ratter, J. A. \& Proctor, J. eds. The nature and Dynamics of the Forest-Savanna Boundary. London, Chapman \& Hall. 499-511.

Raw, A. (1998). Social wasps (Hymenoptera, Vespidae) of the Ilha de Maracá. In: Milliken, W. \& Ratter, J. A. eds. Maracá: The biodiversity and environment of the Amazonian Rainforest. Chichester, John Wiley \& Sons. 307-321

Resende, J.J., Santos, G.M.M., Bichara Filho, C.C. \& Gimenes, M. (2001). Atividade diária de busca de recursos pela vespa social Polybia occidentalis occidentalis (Olivier, 1791) (Hymenoptera, Vespidae). Revista Brasileira de Zoociências, 3: 105-115.

Ribeiro Jr., C., Guimarães, D.L., Elisei, T. \& Prezoto, F. (2006). Foraging activity rhythm of the neotropical swarmfounding wasp Protopolybia exigua (Hymenoptera, Vespidae, Epiponini) in different seasons of the year. Sociobiology, 47: 115-123.

Richards, O.W. (1978). The social wasps of the Americas: Excluding the Vespinae. London, British Museum, 571p.

Richards, O.W. \& M.J. Richards. (1951). Observations on the social wasps of South America (Hymenoptera, Vespidae). Transactions of the Royal Entomological Society of London 102: 1-170.

Richter, M. R. (2000). Social wasp (Hymenoptera: Vespidae) foraging behavior. Annual Review of Entomology, 45: 121150. doi: 10.1146/annurev.ento.45.1.121

Rodrigues, V.M. \& Machado, V.L.L. (1982). Vespídeos sociais: Espécies do Horto Florestal "Navarro de Andrade" de Rio Claro, SP. Naturalia, 7: 173-175.

Santos, B.B. (1996). Ocorrência de vespideos sociais (Hymenoptera, Vespidae) em pomar em Goiânia, Goiás, Brasil. Agrárias, 15: 43-46.

Santos, G.M.M., Filho, C.C.B., Resende, J.J., Cruz, J.D. \& Marques, O.M. (2007). Diversity and community structures of social wasps (Hymenoptera: Vespidae) in three ecosystems in Itaparica Island, Bahia State, Brazil. Neotropical Entomology, 36: $180-185$.

Santos, G. M. M., Aguiar, C.M.L, Mello, M.A.R. (2010). Flower-visiting guild associated with the Caatinga flora: trophic interaction networks formed by social bees and social wasps with plants. Apidologie, 41: 466-475.

Santos, G. M. M., Bispo, P. C., Aguiar, C.M.L. (2009). Fluctuations in Richness and Abundance of Social Wasps During the Dry and Wet Seasons in Three PhytoPhysiognomies at the Tropical Dry Forest of Brazil. Environmental Entomology, 38: 1613-1617.

Santos, G.M.M., Cruz, J.D., Marques, O.M \& Gobbi, N. (2009). 
Diversidade de vespas Sociais (Hymenoptera: Vespidae) em áreas de cerrado na Bahia. Neotropical Entomology, 38: 317320. doi: 10.1590/S1519-566X2009000300003

Sena, J.P.O., Melo, J.S., Lucena, D.B. \& Melo, E.C.S. (2012). Comparação entre dados de chuva derivados do Climate Prediction Center e observados para a região do Cariri Paraibano. Revista Brasileira de Geografia Física, 2: 412-420.

Silva, E.R. \& Noda, S.C.M. (2000). Aspectos da atividade forrageadora de Mischocyttarus cerberus styx Richards, 1940 (Hymenoptera, Vespidae): duração das viagens, especialização individual e ritmo de atividade diário e sazonal. Revista Brasileira de Zoociências, 2: 7-20.

Silva, S. S., Azevedo, G. G.\& Silveira, O.T. (2011). Social wasps of two Cerrado localities in the northeast of Maranhão state, Brazil (Hymenoptera, Vespidae, Polistinae). Revista Brasileira de Entomologia, 55: 597-602. doi: 10.1590/S008556262011000400017

Silva, S.S. \& Silveira, O.T. (2009). Vespas sociais (Hymenoptera, Vespidae, Polistinae) de floresta pluvial Amazônica de terra firme em Caxiuanã, Melgaço, Pará. Iheringia, Série Zoologia, 99: 317-323. doi:10.1590/S007347212009000300015

Silva, N.J.J., Morais, T.A., Santos-Prezoto, H.H. \& Prezoto,, F. (2013). Inventário Rápido de Vespas Sociais em Três Ambientes com Diferentes Vegetações. EntomoBrasilis, 6: 146-149. doi:10.12741/ebrasilis.v6i2.303

Silva-Pereira, V. \& Santos, G.M.M. (2006). Diversity in bee (Hymenoptera: Apoidea) and social wasp (Hymenoptera: Vespidae, Polistinae) community in "campos rupestres", Bahia, Brazil. Neotropical Entomology, 35: 163-174. doi: 10.1590/S1519-566X2006000200003

Silveira, O.T. (2002). Surveying Neotropical social wasps. An evaluation of methods in the "Ferreira Penna" research station (ECFPn), in Caxiuanã, PA, Brazil (Hymenoptera, Vespidae, Polistinae). Papéis Avulsos de Zoologia, 42: 299-
323. doi: 10.1590/S0031-10492002001200001

Simões, M.H., Cuozzo, M.D. \& Friero-Costa, F.A. (2012). Diversity of social wasps (Hymenoptera, Vespidae) in Cerrado biome of the southern of the state of Minas Gerais, Brazil. Iheringia, Série Zoologia, 102: 292-297. doi: 10.1590/ S0073-47212012000300007

Souza, M. M. \& Prezoto, F. (2006). Diversity of Social Wasps (Hymenoptera: Vespidae) in Semidecidous Forest and Cerrado (Savanna) regions in Brazil. Sociobiology, 47: 135147.

Souza, M.M., Louzada, J., Serrao, J.E. \& Zanuncio, J.C. (2010). Social wasps (Hymenoptera: Vespidae) as indicators of conservation degree of Riparian Forests in Southeast Brazil. Sociobiology, 56: 387-396.

Souza, A.R., Venâncio, D.F.A., Zanuncio, J.C. \& Prezoto, F. (2011). Sampling methods for assessing social wasps species diversity in a eucalyptus plantation. Journal of Economic Entomology 104: 1120-1123. doi: 10.1603/EC11060

Souza, M.M., Pires, E.P., Ferreira, M., Ladeira, T.E., Pereira, M., Elpino-Campos, A. \& Zanuncio, J.C. (2012). Biodiversidade de vespas sociais (Hymenoptera: Vespidae) do Parque Estadual do Rio Doce, Minas Gerais, Brasil. MGBiota, 5: 4-19.

Souza, M.M., Pires, E.P. \& Prezoto, F. (2014a). Seasonal richness and composition of social wasps (Hymenoptera: Vespidae) in areas of Cerrado biome in Barroso, Minas Gerais, Brazil. Bioscience Journal, 30: 539-545.

Souza, M.M., Pires, E.P., Elpino-Campos, A. \& Louzada, J.N.C. (2014b). Nesting of social wasps (Hymenoptera: Vespidae) in a riparian forest of rio das Mortes in southeastern Brazil. Acta Scientarum, 36: 189-196. doi: 10.4025/ actascibiolsci.v36i2.21460

Tanaka Junior, G. M., \& Noll, F. B. (2011). Diversity of social wasps on semideciduous seasonal forest fragments with different surrounding matrix in Brazil. Psyche: A Journal of Entomology. doi: 10.1155/2011/861747 